\title{
Management of knotted ureteral stent: A case report and comprehensive review of literature
}

\author{
Zhen Wei Choo ${ }^{1,2 *}$, Seok Kwan Hong ${ }^{1,2}$ and Yee Mun Lee ${ }^{1,2}$ \\ ${ }^{1}$ Tan Tock Seng Hospital, Department of Urology, Singapore \\ ${ }^{2}$ Lee Kong Chian School of Medicine, Nanyang Technological University, Singapore
}

\begin{abstract}
A knotted ureteral stent is an infrequent complication that represents a technical challenge for urologists to treat. The patient's medical record was obtained from our institution's medical database. An extensive review of PubMed was performed using keywords of knotted stent and adult. The parameters examined include use of multi-length or fixed-length stent, configuration of the stent such as single or double J stent, size of the stent, location of knot, underlying pathology, and techniques used to remove it. We hereby report our case study in which we employ the use of ureteroscopy and Holmium laser to remove a knotted stent under general anaesthesia. The stent was previously inserted after definitive treatment of an obstructed distal ureteric stone by ureteroscopy and laser lithotripsy. Multi-length double $\mathrm{j}$ stent remains the most common predisposing risk factor. A smaller size ureteric stent does not increase the risk. The most common site of knot formation is the proximal end of the stent. Ureteroscopy and Holmium laser remain a favoured choice for initial treatment. Limitation of use includes narrow ureter calibre. Ureteroscopy and Holmium laser management of knotted stent is an acceptable first-line approach for its safety and reliability.
\end{abstract}

\section{Introduction}

A knotted ureteral stent was first described by Groeneveld et al. in 1989 in Singapore. It was a double-J ureteric stent inserted to treat renal stones by ESWL, which was successfully removed by simple traction $[1]$.

Incidence of a knotted ureteral stent is very rare in the literature. These retained stents had different configurations (e.g.: single-J, double-J and multi-length ureteral stent) [2]. Multi-length ureteral stents can be as long as $22-32 \mathrm{~cm}$ depending on the manufacturer.

Among the many reported risk factors include the consistency and diameter of the stent, alteration of coil configuration during removal, the number of coils made by the multi-length stent coils, presence of stent encrustation and surgeon's experience in insertion [3-5].

Management options for removal of knotted stent includes removal with simple gentle traction with or without adjuncts such as Valsalva maneuver or lubrication, stiff guidewire manipulation for unknotting, ureteroscopy with holmium laser, percutaneous nephrostomy removal or open ureterotomy [6]. An updated literature review was also performed. To date, there has not been a consensus on the most acceptable initial approach. In our study we will review all the available literature on the management strategies

To the best of our knowledge, this is the $2^{\text {nd }}$ knotted stent to be reported from Southeast Asia after Groenevald et al. [1], in 1989. However, it's our believe that these cases are likely to be under reported. (Table 1 and Figures 1-4)

\section{Materials and methods}

The patient's medical record was obtained from our institution's medical data base. An extensive review of PubMed was performed for an up-to-date review of the literature for cases of knotted ureteric stent in adults. The parameters examined include the use of multi length or fixed length ureteric stent, the configuration either single or double, the diameter, location of the knot formed, underlying pathology and technique used to remove it.

\section{Case report}

A 73-year-old Singaporean Chinese male presented to our hospital's emergency department with complains of left ureteric colic, fever, and dysuria. He had a history of previous ureteric stone which was managed by medical expulsion therapy (MET) with alpha blockers. Computerized tomography scans showed a $9 \mathrm{~mm}$ left ureteric calculus. A double J (DJ) ureteric stent was inserted retrogradely under general anesthesia, and subsequently elected for conservative management with MET. Interval CT scans then showed that the previously seen left ureteric stone had passed out and only a tiny $0.4 \mathrm{~cm}$ renal stone remains in the lower pole. Due to delays caused by MET, the stent was only scheduled for removal 3 months from the last insertion. Resistance was felt during the retrieval at the point where the distal coil of stent was exteriorized to the urethral meatus. Xray KUB demonstrated a knot at proximal coil in the proximal ureter at about L4 level. He was then arranged for an emergency procedure to remove the knotted stent in the operating theatre. Another attempt at gentle tract of the stent was made once patient was under general anesthesia but wasn't successful. We managed to successfully advance a Sensor guidewire (Boston Scientific, MA, USA) past the proximal DJ stent knotted coil into the renal pelvis. A dual lumen catheter $10 \mathrm{Fr}$ (Boston Scientific, MA, USA)

${ }^{\star}$ Correspondence to: Zhen Wei Choo, Tan Tock Seng Hospital, Department of Urology, Singapore, E-mail: zwchoo@gmail.com

Key words: Knotted stent, Adult, Ureteroscopy, Holmium laser, Multi-length

Received: June 01, 2021; Accepted: June 21, 2021; Published: June 28, 2021 


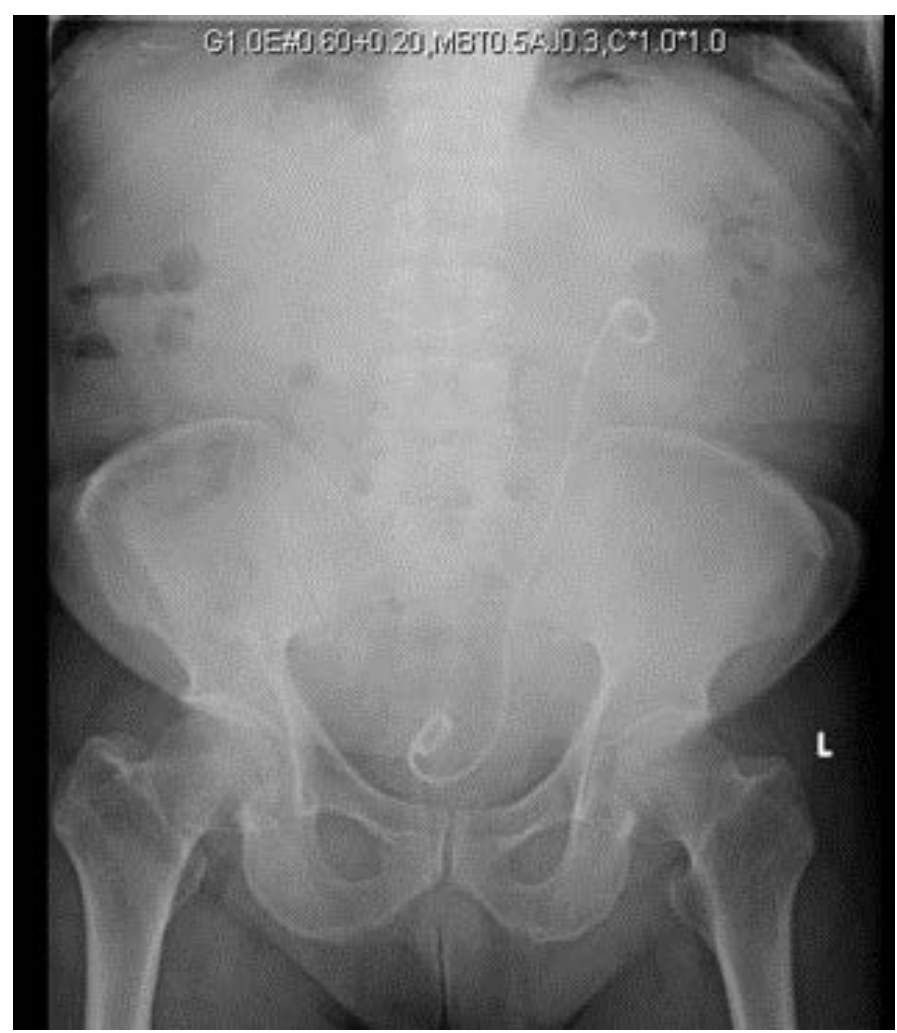

Figure 1. XR KUB Position of Left DJ stent prior to removal

was railroaded via the guidewire to just below the knot. A retrograde pyelogram (RPG) was then performed. A second Super Stiff ${ }^{\mathrm{TM}}$ guidewire was placed in the renal pelvis as safety. The Sensor guidewire was then backloaded into the semi-rigid ureteroscope and introduced into the ureter up to the level of the DJ stent knot. The lateral edge of the knot was lasered using Holmium laser lithotripsy using $600 \mathrm{~mJ}$ and $6 \mathrm{~Hz}$, enough that it can move within the lumen of the ureter. Subsequently, smooth traction was applied, and complete removal of the knotted ureteric stent was performed under direct ureteroscopic view. RPG was again performed at the end of procedure with no extravasation. The configuration of the knotted stent was compared radiographically pre and post procedure to show that no fragments may have dislodged proximally. A 6Fr Versafit ${ }^{\mathrm{TM}}$ (C. R. BARD Inc., Covington, GA, USA) DJ ureteric stent was placed, and good position confirmed on fluoroscopy imaging. We kept the stent for 2 weeks before removing it uneventfully.

\section{Discussion}

\section{Location of knot and ureteric stent configuration}

Almost all the cases reported knot formation in the upper part of the stent with only 2 cases each reported distal by Das et al and in the mid ureter by Quek et al. respectively $[7,8]$. Even though the mechanism for formation of knot at the mid ureter in this case is unknown, the authors speculated that the underlying anatomy of cystocele may have caused the bladder to displace with postural changes and allowed the stent to buckle. The distal knot stent mechanism is unknown. All the cases involved the use of double J ureteric stent except one case by Das et al. [7].

\section{Predisposing factor to knotted stent}

In a case series by Manohar et al. 3 out of 4 cases involve the use of size 4.8 Fr diameter stent [9]. 3 of our cases did not report on the size of the stent used. However, there were many cases which reported knot formation in larger stent size with $6 \mathrm{Fr}$ in 11 cases and $7 \mathrm{Fr}$ in 9 cases. Hence, smaller size ureteric stent is less likely a risk factor as previously presumed.

21 out of 32 cases of knotted ureteral stents revealed the use of multi-length double J ureteric stent. Theoretically, the longer the length of ureteral stent in the kidney, more likely the possibility for it to knot on its end $[6,10]$. It was hypothesized that the excessive length causes one end of the stent abutting the wall to subsequently pass through an open loop [8]. This biased observation could also be attributed to fact that it's more widely used than the fixed length [4]. In addition, clinicians tend to increase the amount coils in the kidney the hope that this reduces the frequency of stent-related symptoms. Nevertheless, a study by Calvert et al. demonstrated that no difference in stent related symptoms when compared between fixed $24 \mathrm{~cm}$ length and multi- length DJ stent [11]. Hence, there is no advantage to increase the number of coils in the kidney to reduce the distal coil in bladder to improve stent related symptoms. Whether or not fixed length stents reduces the risk of coiling is still debatable as the available evidence based on case reports alone is weak.

The most common risk factor was the use of multi length stent that was attributed by co-factors such as absence of hydronephrosis or presence of encrustations. Kim et al. [6] had hypothesized that the absence of hydronephrosis increases the chance of ureteral stent knot formation.

\section{Ureteroscopy and holmium laser}

For the various methods to remove knotted stents, our literature review showed that the underlying cause appears to be associated with the methodology employed. Majority of those related to ureteric stone disease, which has a higher risk of stent encrustations, the preferred choice appears to be ureteroscopy and Holmium laser. Meanwhile, for those related to promotion of ureteric anastomosis healing or prophylactically insertion prior to ESWL for renal stones, gentle traction with or without adjuncts appears to be the preferred choice.

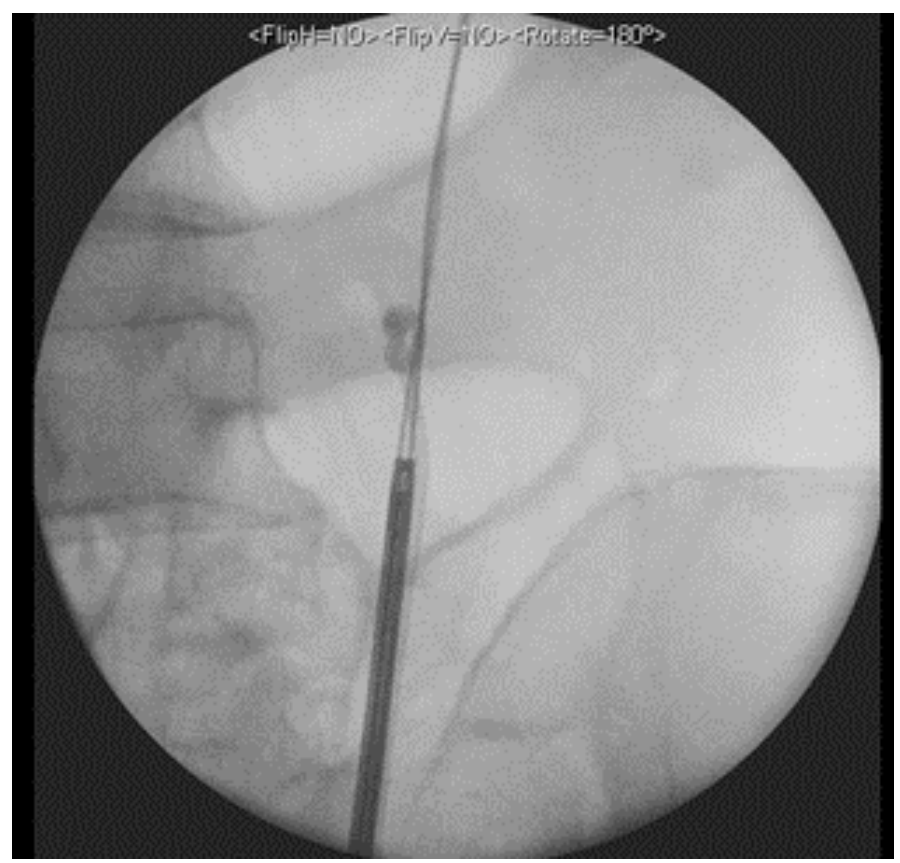

Figure 2. Location of the proximal knotted stent at vertebrae L4 level 


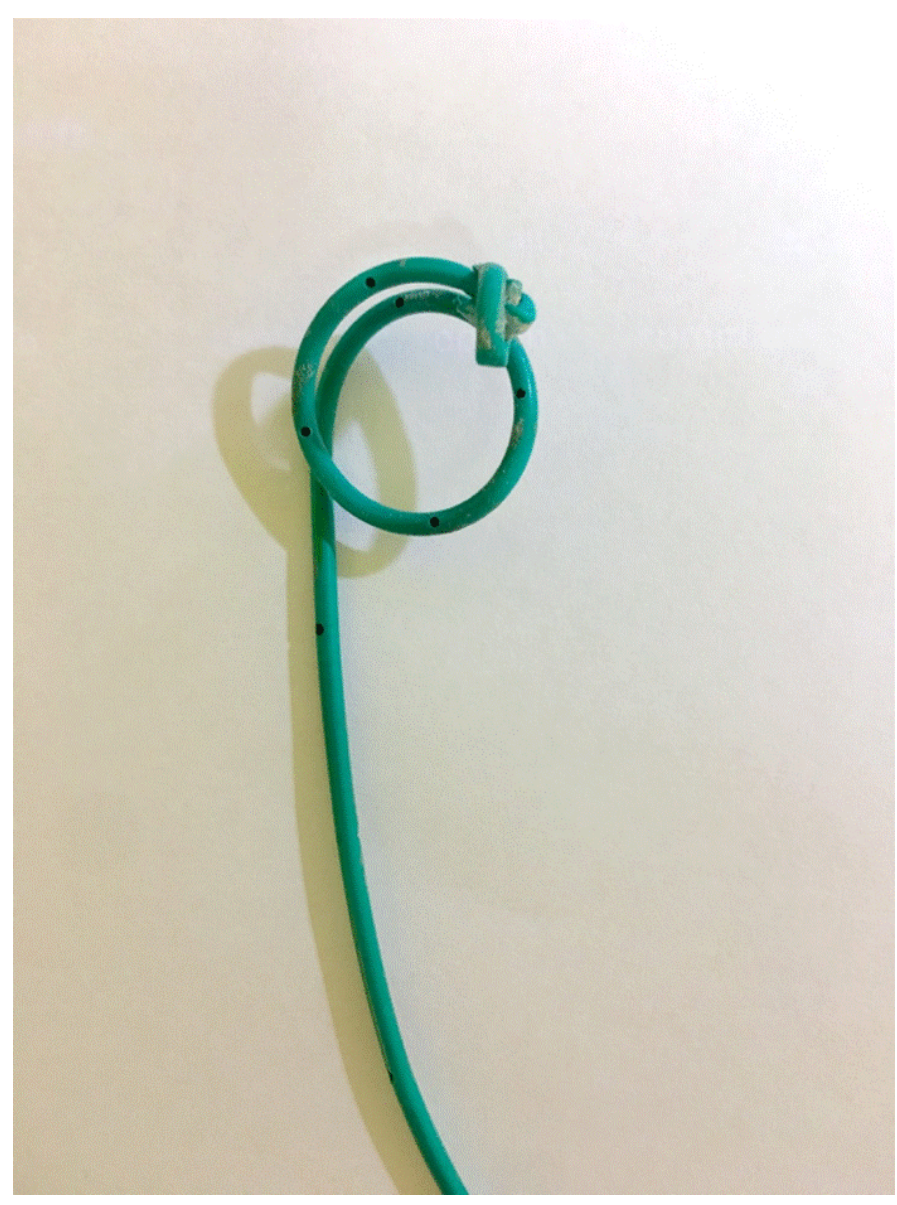

Figure 3. Knotted proximal ureteric stent

Meanwhile the use of Holmium laser had only been reported in 5 other papers to date; Richards et al being the pioneer, Tempest et al. Nettle et al. Ahmadi et al. and Manohar et al. [5,9,12-14]. The choice of laser is Holmium:YAG (Yttrium Aluminum Garnet). Nevertheless, there is no mention of the energy or frequency used. For our case, we used the standard setting of $600 \mathrm{~mJ}$ and $6 \mathrm{~Hz}$. Except for Tempest et al who described breaking the stent into 2 pieces, the other studies lasered the knot to many pieces and one had the stent transected. Our technique differs from those already mentioned as it involves aiming our laser tip to the knot of the stent, just enough to loosen it off the wall and combined with smooth gentle traction applied at the exteriorized end of the stent, we were able to retrieve it completely.

No reported complications such as ureteric injury was revealed in all these cases. However, important consideration during this procedure is the need for retrograde access which can be difficult in cases with narrow ureter caliber and the possibility of the broken off ureteric stent segments migrating proximally and retained as foreign body in the urinary system.

Out of a total of 12 cases reported in literature regarding the use of ureteroscopy with Holmium laser $(n=11)$ or forceps manipulation $(n=1)$ for management of knotted stent, only 3 were not successful, requiring further or repeat intervention. 2 cases in our literature review reported on the difficulty in retrograde access due to narrow ureter caliber whereby they were not able to reach the knot. Their strategy includes the use of laser to transect the stent and pushing the proximal segment into the kidney with a flexible ureterorenoscopy, which was then retrieved by percutaneous method later on [3,5]. Lastly, Flam et al. [15] chose to insert a $2^{\text {nd }}$ Double J stent to promote dilatation of the ureter before proceeding to remove the knotted stent by untying the knot using a $5 \mathrm{Fr}$ alligator forceps.

Percutaneous retrieval has mostly been used as a secondary procedure instead of a primary as due to its invasive nature and has only been reported in 5 cases. One example is Bhirud et al. [16] who performed it as a primary measure as they were able to access percutaneously to retrieve the stent due to preexisting tract created from the initial procedure of PCNL of the renal stone.

Only one case of ureterotomy was described by Kondo et al. [17]. However, details of the case were not clear in view the paper was written mostly in Japanese. It was described that the stent was initially inserted for ESWL to renal stones and subsequent formation of proximal knot. Nevertheless, no other paper in the literature had required the use of ureterotomy for access to remove the stent.

Majority of gentle traction methods has been reported as simple. However one case reported the use of Vaseline as an adjunct manueverwhile another used continuous traction for 3 days by tying the distal coil with a common catheter strip to the leg and combined with ESWL to the site of knot encrustation $[10,18]$. All these gentle tractions were done under local anesthesia except for the Valsalva maneuver which was performed under general anesthesia. The use of lubrication such as sterile Vaseline by direct injection into the ureter through a $10 \mathrm{ml}$ syringe as described by Rivalta $e t$ al was used in a patient with ureterocutaneous anastomosis [19-25]. This method, however, may prove more challenging in an endoscopic approach. The use of Valsalva maneuver as suggested was only documented in one study by Eisner et al and was only retrospectively speculated. The authors believe that Valsalva effect caused by repeated bouts of coughing during difficult anesthesia attempts may have uncoiled the stent internally. This, however, has not been proven to be a method in any other literature.

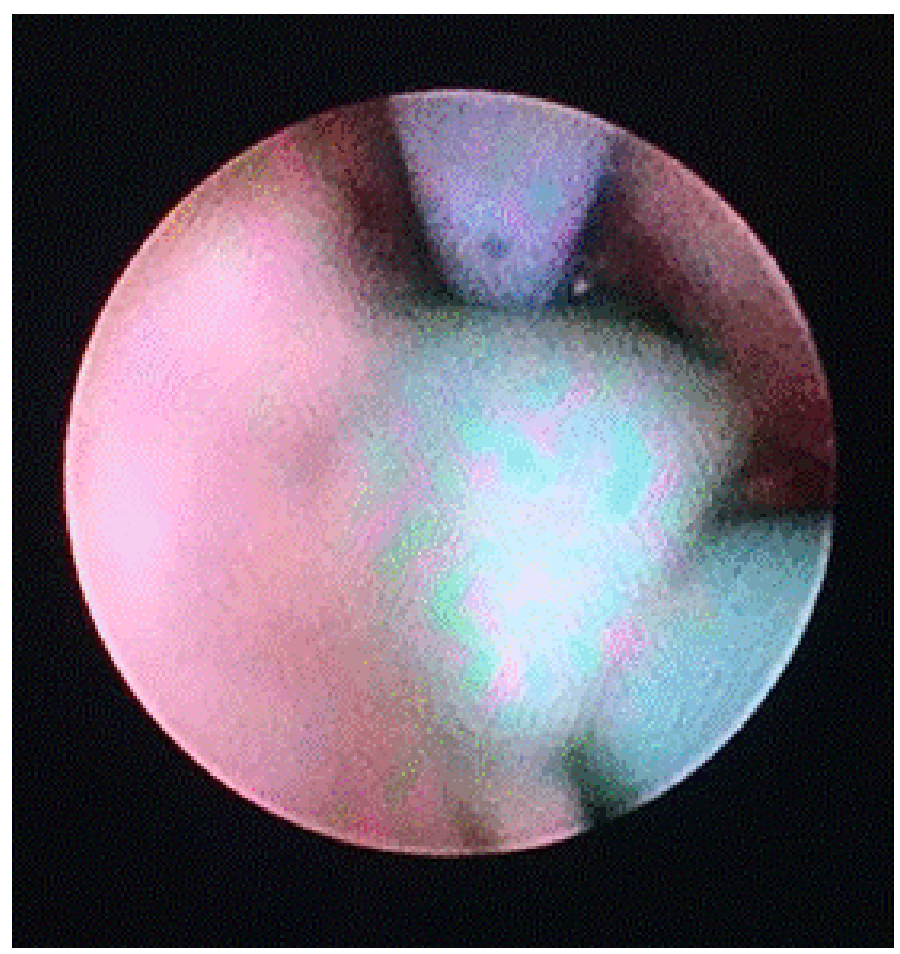

Figure 4. Endoscopic view of the proximal knotted stent 
Table 1. Literature review of knotted stents

\begin{tabular}{|c|c|c|c|c|c|c|c|c|c|c|}
\hline No & Author & $\begin{array}{c}\text { Age/ } \\
\text { Gender }\end{array}$ & Year & \begin{tabular}{|c|} 
Multi-length or \\
Fixed length
\end{tabular} & $\begin{array}{l}\text { Ureteric Stent } \\
\text { configuration }\end{array}$ & Diameter & $\begin{array}{c}\text { Location of } \\
\text { knot }\end{array}$ & Underlying pathology & Technique of removal & $\begin{array}{l}\text { Complica- } \\
\text { tion }\end{array}$ \\
\hline 1 & Groeneveld et al (1) & NA & 1989 & NA & Double J stent & NA & Upper & Renal stone for ESWL & Gentle traction & Nil \\
\hline 2 & Das et al (7) & $45 / \mathrm{M}$ & 1990 & NA & Single $\mathrm{J}$ stent & NA & Distal & Renal stone for ESWL & Gentle traction & Nil \\
\hline 3 & Braslis et al (3) & $37 / \mathrm{F}$ & 1992 & Multi-length & Double J stent & $4.7 \mathrm{Fr}$ & Upper & Renal stone for ESWL & $\begin{array}{c}\text { Initial ureteroscopy failed, } \\
\text { needed percutaneous neph- } \\
\text { rostomy removal }\end{array}$ & Nil \\
\hline 4 & Kundagi et al (20) & $53 / \mathrm{M}$ & 1994 & Multi-length & Double J stent & $6 \mathrm{Fr}$ & Upper & Renal stone for ESWL & $\begin{array}{c}\text { Percutaneous nephrostomy } \\
\text { removal }\end{array}$ & Nil \\
\hline 5 & Flam et al (15) & $86 / \mathrm{M}$ & 1995 & $\begin{array}{l}\text { Fixed length } \\
(26 \mathrm{~cm})\end{array}$ & Double J stent & $6 \mathrm{Fr}$ & Upper & $\begin{array}{l}\text { Relief of obstructive uropathy } \\
\text { (upper ureteric stone) }\end{array}$ & $\begin{array}{l}\text { Delayed for } 1 \text { week with } \\
\text { Interim insertion of } 2^{\text {nd }} \\
\text { DJ stent } \\
\text { Unknotting by ureteros- } \\
\text { copy and } 5 \mathrm{Fr} \text { alligator } \\
\text { forceps }\end{array}$ & Nil \\
\hline 6 & Baldwinn et al (21) & $73 / \mathrm{M}$ & 1998 & Multi-length & Double J & $7 \mathrm{Fr}$ & Upper & $\begin{array}{l}\text { Promote healing of the ureter } \\
\text { (post left distal ureterectomy } \\
\text { and reimplant complicated by } \\
\text { stricture) }\end{array}$ & $\begin{array}{c}\text { Guidewire (Superstiff) to } \\
\text { untie the knot }\end{array}$ & Nil \\
\hline 7 & Quek M et al (8) & $66 / F$ & 2002 & Multi-length & Double J & $7 \mathrm{Fr}$ & Mid & $\begin{array}{l}\text { Relief of obstructive uropathy } \\
\text { (Upper ureteric stone) }\end{array}$ & Gentle traction & Nil \\
\hline 8 & Sighinolfi et al (10) & $48 / \mathrm{M}$ & 2005 & $\begin{array}{l}\text { Multi-length } \\
(22-32 \mathrm{~cm})\end{array}$ & Double J & $5 \mathrm{Fr}$ & Upper & $\begin{array}{c}\text { Relief of obstructive uropathy } \\
\text { (Staghorn calculus) }\end{array}$ & $\begin{array}{c}\text { Continuous traction for } 3 \\
\text { days and ESWL }\end{array}$ & Nil \\
\hline 9 & Kondo et al(17) & $37 / \mathrm{M}$ & 2005 & $\begin{array}{l}\text { Multi-length } \\
(22-32 \mathrm{~cm})\end{array}$ & Double J & $7 \mathrm{Fr}$ & Upper & Renal stone for ESWL & Ureterotomy & Nil \\
\hline 11 & Eisner et al (18) & $82 / \mathrm{F}$ & 2006 & $\begin{array}{l}\text { Multi-length }(22- \\
32 \mathrm{~cm})\end{array}$ & $\begin{array}{c}\text { Double J } \\
\text { (Cook urological } \\
\text { inc, Spencer, IN, } \\
\text { USA) }\end{array}$ & $6 \mathrm{Fr}$ & Upper & Renal stone for ESWL & Gentle traction (Valsalva) & Nil \\
\hline 12 & Basavaraj et al (22) & $70 / \mathrm{F}$ & 2007 & $\begin{array}{l}\text { Multi-length }(22- \\
32 \mathrm{~cm})\end{array}$ & $\begin{array}{c}\text { Double J } \\
\text { (Cook urological } \\
\text { inc, Spencer, IN, } \\
\text { USA) }\end{array}$ & $7 \mathrm{Fr}$ & Upper & $\begin{array}{l}\text { Promote healing of the ureter } \\
\text { (post flexible ureteroreno- } \\
\text { scopy for ureter and renal } \\
\text { stones) } \\
\text { Background of Ileal conduit }\end{array}$ & $\begin{array}{l}\text { Delayed for } 3 \text { weeks with } \\
\text { interim PCN and subse- } \\
\text { quent gentle traction }\end{array}$ & Nil \\
\hline 13 & Rivalta et al (19) & $83 / \mathrm{M}$ & 2009 & Fixed length & Single -J & $7 \mathrm{Fr}$ & Upper & $\begin{array}{l}\text { Promote healing of the uret- } \\
\text { erocutaneous anastomosis } \\
\text { (Ureterocutaneous anastomo- } \\
\text { sis for bladder cancer) }\end{array}$ & $\begin{array}{c}\text { Gentle traction with vase- } \\
\text { line lubrication }\end{array}$ & Nil \\
\hline 14 & Picozzi et al (4) & $41 / \mathrm{F}$ & 2010 & $\begin{array}{c}\text { Fixed length }(26 \\
\mathrm{cm})\end{array}$ & Double J & $7 \mathrm{Fr}$ & Upper & $\begin{array}{l}\text { Promote healing of the } \\
\text { ureteroneocystosomy anasto- } \\
\text { mosis after pelvic surgery for } \\
\text { endometriosis }\end{array}$ & Gentle traction & Nil \\
\hline 15 & Tempest et al (13) & NA & 2011 & NA & Double J & NA & Upper & NA & $\begin{array}{l}\text { Ureteroscopy and Hol- } \\
\text { mium laser }\end{array}$ & Nil \\
\hline 16 & Richards et al (12) & $67 / \mathrm{M}$ & 2011 & NA & Double J & NA & Upper & $\begin{array}{l}\text { Relief of obstructive uropathy } \\
\text { (upper ureteric stone }\end{array}$ & $\begin{array}{l}\text { Ureteroscopy and Hol- } \\
\text { mium laser }\end{array}$ & Nil \\
\hline 17 & Moufid et al (2) & $32 / \mathrm{M}$ & 2012 & NA & Double J & $7 \mathrm{Fr}$ & Upper & $\begin{array}{l}\text { Relief of obstructive uropathy } \\
\text { (upper ureteric stone) }\end{array}$ & $\begin{array}{c}\text { Delayed for } 3 \text { days with } \\
\text { interim } 2^{\text {nd }} \mathrm{DJ} \text { stent inser- } \\
\text { tion and subsequent gentle } \\
\text { traction }\end{array}$ & Nil \\
\hline 18 & Karaguzel et al (23) & $53 / \mathrm{M}$ & 2012 & $\begin{array}{l}\text { Fixed length } \\
\quad(28 \mathrm{~cm})\end{array}$ & Double J & 4.7 Fr & Upper & $\begin{array}{l}\text { Relief of obstructive uropathy } \\
\quad \text { (upper ureteric stone) }\end{array}$ & $\begin{array}{c}\text { Ureteroscopy and laser } \\
\text { with Gentle traction using } \\
\text { foreign body forceps }\end{array}$ & Nil \\
\hline 19 & Nettle et al (14) & $43 / \mathrm{M}$ & 2012 & Multi-length & Double J & $7 \mathrm{Fr}$ & Upper & $\begin{array}{l}\text { Ureter identification intraop- } \\
\text { erative } \\
\text { (laparotomy with division of } \\
\text { adhesions and resiting of il- } \\
\text { eostomy post total colectomy } \\
\text { for Crohn's disease) }\end{array}$ & $\begin{array}{l}\text { Ureteroscopy and Hol- } \\
\text { mium laser }\end{array}$ & Nil \\
\hline 20 & Bhirud et al (16) & $41 / \mathrm{M}$ & 2012 & NA & Double J & NA & Upper & Exit strategy post PCNL & $\begin{array}{c}\text { Percutaneous removal with } \\
26 \mathrm{~F} \text { nephroscope }\end{array}$ & Nil \\
\hline
\end{tabular}




\begin{tabular}{|c|c|c|c|c|c|c|c|c|c|c|}
\hline \multirow{5}{*}{21} & Ahmadi et al (5) & & & & & & & & & \\
\hline & Case 1 & $45 / \mathrm{M}$ & 2015 & Multi-length & $\begin{array}{c}\text { Double J } \\
\text { (Cook urological } \\
\text { inc, Spencer, IN, } \\
\text { USA) }\end{array}$ & $6 \mathrm{Fr}$ & Upper & $\begin{array}{l}\text { PUJ calculus - staged pro- } \\
\text { cedure }\end{array}$ & $\begin{array}{l}\text { Ureteroscopy and Hol- } \\
\text { mium laser }\end{array}$ & Nil \\
\hline & Case 2 & $43 / \mathrm{M}$ & 2015 & Multi-length & $\begin{array}{c}\text { Double J } \\
\text { (Cook urological } \\
\text { inc, Spencer, IN, } \\
\text { USA) }\end{array}$ & $6 \mathrm{Fr}$ & Upper & $\begin{array}{l}\text { Upper ureteric calculus - } \\
\text { staged procedure }\end{array}$ & $\begin{array}{l}\text { Ureteroscopy and Hol- } \\
\text { mium laser }\end{array}$ & Nil \\
\hline & Case 3 & $71 / \mathrm{M}$ & 2015 & Multi- length & $\begin{array}{c}\text { Double J } \\
\text { (Cook urological } \\
\text { inc, Spencer, IN, } \\
\text { USA) } \\
\end{array}$ & $7 \mathrm{Fr}$ & Upper & $\begin{array}{l}\text { Relief of obstructive uropathy } \\
\text { (Retroperitoneal fibrosis) }\end{array}$ & $\begin{array}{c}\text { Ureteroscopy and laser to } \\
\text { proximal fragment, Staged } \\
\text { procedure, percutaneous } \\
\text { retrieval at later date }\end{array}$ & Nil \\
\hline & Case 4 & $55 / \mathrm{M}$ & 2015 & Multi- length & $\begin{array}{c}\text { Double J } \\
\text { (Cook urological } \\
\text { inc, Spencer, IN, } \\
\text { USA) } \\
\end{array}$ & $6 \mathrm{Fr}$ & Upper & $\begin{array}{l}\text { Relief of obstructive uropathy } \\
\text { (upper ureteric stone) }\end{array}$ & $\begin{array}{l}\text { Ureteroscopy and Hol- } \\
\text { mium laser }\end{array}$ & Nil \\
\hline 22 & Kim et al (6) & $53 / \mathrm{M}$ & 2015 & Multi- length & NA & $6 \mathrm{Fr}$ & Upper & Renal stone for EsWL & $\begin{array}{c}\text { Percutaneous removal with } \\
\text { folded Terumo Guidewire }\end{array}$ & Nil \\
\hline \multirow[t]{5}{*}{23} & Manohar et al (9) & & & & & & & & & \\
\hline & Case 1 & $65 / \mathrm{M}$ & 2015 & $\begin{array}{l}\text { Multi-length } \\
(24-32 \mathrm{~cm})\end{array}$ & $\begin{array}{c}\text { Double J } \\
\text { (Boston scientific, } \\
\text { MA, USA) }\end{array}$ & $4.8 \mathrm{Fr}$ & Upper & $\begin{array}{l}\text { Relief of obstructive uropathy } \\
\text { (Upper Ureteric calculus) }\end{array}$ & $\begin{array}{l}\text { Staged percutaneous ante- } \\
\text { grade removal }\end{array}$ & Nil \\
\hline & Case 2 & $65 / \mathrm{F}$ & 2015 & $\begin{array}{l}\text { Multi-length (24- } \\
\quad 32 \mathrm{~cm})\end{array}$ & NA & $4.8 \mathrm{Fr}$ & Upper & $\begin{array}{l}\text { Promote ureteric healing } \\
\text { (Mid ureter injury - laparo- } \\
\text { scopic bilateral salpingo- } \\
\text { oophorectomy) }\end{array}$ & Ureteroscopy and laser & Nil \\
\hline & Case 3 & $55 / \mathrm{F}$ & 2015 & $\begin{array}{l}\text { Multi-length } \\
(22-30 \mathrm{~cm})\end{array}$ & NA & $6 \mathrm{Fr}$ & Upper & $\begin{array}{c}\text { Promote ureter healing and } \\
\text { prophylactic relief of obstruc- } \\
\text { tive uropathy } \\
\text { (post incomplete RIRS for } \\
\text { renal stone) }\end{array}$ & Ureteroscopy and laser & Nil \\
\hline & Case 4 & $59 / \mathrm{M}$ & 2015 & $\begin{array}{l}\text { Multi-length } \\
(24-32 \mathrm{~cm}, 22- \\
30 \mathrm{~cm})\end{array}$ & NA & $4.8 \mathrm{Fr}$ & Upper & $\begin{array}{l}\text { Promote ureter healing and } \\
\text { prophylactic relief of obstruc- } \\
\text { tive uropathy } \\
\text { (Post complete RIRS for left } \\
\text { renal stone - difficulty during } \\
\text { routine insertion }\end{array}$ & Gentle traction & Nil \\
\hline 24 & Bradshaw et al (24) & $57 / \mathrm{F}$ & 2020 & NA & NA & NA & Upper & $\begin{array}{l}\text { Bilateral obstructive uropathy } \\
\text { with right nephrostomy tube. } \\
\text { Difficulty encountered during } \\
\text { removal attempt via } 8 \text { F neph- } \\
\text { rostomy sheath }\end{array}$ & $\begin{array}{l}\text { Antegrade removal of a } \\
\text { knotted ureteric stent by di- } \\
\text { lating the tract up to } 15 \mathrm{~F}\end{array}$ & Nil \\
\hline 25 & Cho et al (25) & $62 / \mathrm{M}$ & 2020 & $\begin{array}{l}\text { Multi-length } \\
(22-32 \mathrm{~cm})\end{array}$ & $\begin{array}{c}\text { Double J } \\
\text { (C. R. BARD Inc., } \\
\text { Covington, GA, } \\
\text { USA) } \\
\end{array}$ & $6 \mathrm{Fr}$ & Upper & $\begin{array}{l}\text { Promote ureter healing (post } \\
\text { RIRS for ureter stone) }\end{array}$ & $\begin{array}{l}\text { Ureteroscopy to push the } \\
\text { knotted stent into renal pel- } \\
\text { vis and real time fluoros- } \\
\text { copy probing by guidewire }\end{array}$ & Nil \\
\hline 26 & Present study & $73 / \mathrm{M}$ & 2021 & Multi-length & $\begin{array}{c}\text { Double J } \\
\text { (C. R. BARD Inc., } \\
\text { Covington, GA, } \\
\text { USA) } \\
\end{array}$ & $6 \mathrm{Fr}$ & Upper & $\begin{array}{l}\text { Relief of obstructive uropathy } \\
\text { (upper ureteric stone) }\end{array}$ & Ureteroscopy and laser & Nil \\
\hline
\end{tabular}

RIRS - Retrograde intrarenal surgery

URS - Ureteroscopy

NA - Not available 


\section{Conclusion}

The removal of knotted ureteral stent by use of ureteroscopy with Holmium laser to the edge of the knotted stent with combined gentle traction under endoscopic view is safe and effective.

\section{References}

1. Groeneveld AE (1989) The role of ESWL in the treatment of large kidney stones. Singapore Med J 30: 249-254. [Crossref]

2. Moufid K, Touiti D, Mohamed L (2012) "Knot stent": An unusual cause of acute renal failure in solitary kidney. J Clin Imaging Sci 2: 36. [Crossref]

3. Braslis KG, Joyce G (1992) Spontaneous knotting of a pigtail ureteric stent in the ureter requiring percutaneous removal. Aust $N Z J$ Surg 62: 825-826. [Crossref]

4. Picozzi S, Carmignani L (2010) A knotted ureteral stent: A case report and review of the literature. Urol Ann 2: 80-82. [Crossref]

5. Ahmadi N, Tran M, Elms M, Ko R (2015) Knotted proximal loop of ureteric stents: Review of the literature and five case reports. J Clin Urol 8: 432-437.

6. Kim MS, Lee HN, Hwang H (2015) Knotted stents: Case report and outcome analysis. Korean J Urol 56: 405-408. [Crossref]

7. Das G, Wickham JE (1990) Knotted ureteric stent: an unusual urological complication. J R Coll Surg Edinb 35:190. [Crossref]

8. Quek ML, Dunn MD (2002) Knot formation at the mid portion of an indwelling ureteral stent. J Urol 168(4 Pt 1):1497. [Crossref]

9. Manohar P, Kan WT, Ranasinghe WK, Cetti RJ, McCahy P (2016) Knotted multilength ureteric stents: A case series. ANZ J Surg 86: 413-414. [Crossref]

10. Sighinolfi MC, De Stefani S, Micali S, Mofferdin A, Baisi B, et al. (2005) A knotted multi-length ureteral stent: a rare complication. Urol Res 33: 70-71. [Crossref]

11. Calvert RC, Wong KY, Chitale SV, Irving SO, Nagarajan M, et al. (2013) Multilength or $24 \mathrm{~cm}$ ureteric stent? A multicentre randomised comparison of stent-related symptoms using a validated questionnaire. BJU Int 111: 1099-1104. [Crossref]
12. Richards MM, Khalil D, Mahdy A (2011) Successful treatment of stent knot in the proximal ureter using ureteroscopy and holmium laser. Case Rep Med 2011: 502191. [Crossref]

13. Tempest H, Turney B, Kumar S (2011) Novel application of an established technique for removing a knotted ureteric stent. BMJ Case Rep 2011: bcr1120103528. [Crossref]

14. Nettle J, Huang JG, Rao R, Costello AJ (2012) Ureteroscopic holmium laser ablation of a knotted ureteral stent. $J$ Endourol 26: 968-970. [Crossref]

15. Flam TA, Thiounn N, Gerbaud PF, Zerbib M, Debre B (1995) Knotting of a double pigtail stent within the ureter: an initial report. J Urol154:1858-1859. [Crossref]

16. Bhirud P, Giridhar V, Hegde P (2012) Midureteric knotted stent removed by percutaneous access! Urol Ann 4:106-107. [Crossref]

17. Kondo N, Yoshino Y, Shiono Y, Hasegawa Y (2005) A case demonstrating kno formation at the upper end of a ureteral stent. Hinyokika Kiyo 51: 385-387. [Crossref]

18. Eisner B, Kim H, Sacco D (2006) Repeat knot formation in a patient with an indwelling ureteral stent. Int Braz J Urol 32: 308-309. [Crossref]

19. Rivalta M, Sighinolfi MC, Micali S, De Stefani S, Bianchi G (2009) Knotted ureteral catheter in an 83-year-old man: case presentation and urological non-invasive management in the elderly. Urol Res 37: 261-262. [Crossref]

20. Kundargi P, Bansal M, Pattnaik PK (1994) Knotted upper end: A new complication in the use of an indwelling ureteral stent. J Urol 151: 995-996. [Crossref]

21. Baldwin DD, Juriansz GJ, Stewart S, Hadley R (1998) Knotted ureteral stent: a minimally invasive technique for removal. J Urol 159: 2065-2066. [Crossref]

22. Basavaraj DR, Gill K, Biyani CS (2007) Case report: Knotted ureteral stent in patient with ileal conduit: Conservative approach for retrieval. J Endourol 21: 90-93. [Crossref]

23. Karaguzel E, Kutlu O, Kazaz IO, Gur M, Dil E, et al. (2012) Knotted ureteral stent: A rare complication of ureteral stent usage. Urol Res 40: 793-795. [Crossref]

24. Bradshaw J, Khan A, Adiotomre E, Burbidge S, Biyani CS (2020) Antegrade removal of a knotted ureteric stent: Case report and review of literature. Urol Ann 12: 96-100. [Crossref]

25. Cho CL (2020) A knotted ureteral stent. Urology Case Rep 33:101327.

Copyright: (2021 Choo ZW. This is an open-access article distributed under the terms of the Creative Commons Attribution License, which permits unrestricted use, distribution, and reproduction in any medium, provided the original author and source are credited. 